WMJ (Warmadewa Medical Journal), Vol. 3 No. 1 Mei 2018, Hal. 15-20

\title{
Diagnosis and Management of Essential Thrombocythemia in Sanjiwani Hospital Gianyar, Bali: A Case Report
}

\author{
Sri Wardani NW ${ }^{1}$, Ery Purnama Warsana Putra IK ${ }^{1}$, Renny A Rena NM ${ }^{2}$ \\ ${ }^{I}$ Sanjiwani Hospital/Faculty of Medical and Health Sciences, Universitas Warmadewa, Bali, Indonesia \\ ${ }^{2}$ Departement of Internal Medicine, Faculty of Medicine, University of Udayana, Sanglah Hospital, Bali, Indo- \\ nesia \\ Email ${ }^{l}$ :wardani_sppd@yahoo.co.id
}

\begin{abstract}
.
Essential thrombocythemia (ET) is a very rare disorder with $1-/ 100,000$ population in the world. The incidence of this abnormality is still obscure in Indonesia. We report a case of ET, women of age 74 years old that came to Sanjiwani Hospital with gum bleeding. This case is confirmed based on WHO criteria of ET which are the increasing of thrombocyte of a number of increase $>450 / \mu \mathrm{L}^{3}$, proliferation of megakaryocyte cell on bone marrow biopsy, also not meeting any other WHO criteria for also not meeting any other WHO criteria for BCR-ABL1 ${ }^{+}$CML, Polycythemia Vera, Chronic Myeloid Leukemia, Myelodysplastic Syndrome, or other myeloid neoplasm diseases. Management of this case is based on risk adapted treatment algorithm considering three major risk factors for thrombosis (history of thrombosis, JAK2/MPL mutations, and advanced age). This case is categorized as high risk patient for thrombosis, so that treated with antiplatelet aggregation (aspilets) and anagrelide after hydroxyurea clinically unresponsive.
\end{abstract}

Keywords: Essential Thrombocythemia, Thrombosis, Haemorrhage

\section{Abstrak}

Trombositemia esensial (TE) adalah gangguan yang sangat jarang terjadi yaitu 1-2/100.000 penduduk di dunia. Insiden kelainan ini masih tidak jelas di Indonesia. Kami melaporkan sebuah kasus TE, seorang perempuan, 74 tahun yang datang ke Rumah Sakit Umum Sanjiwani dengan keluhan perdarahan gusi. Diagnosis Kasus ini ditegakkan berdasarkan kriteria WHO 2016 dari TE di mana jumlah trombosit meningkat $>450 / \mu L$ adanya proliferasi sel megakariosit pada biopsi sumsum tulang, dan tidak memenuhi kriteria WHO dari BCR-ABL $1^{+}$Chronic Myeloid Leukemia (CML), Polycythemia Vera (PV), Myelodysplastic Syndrome (MDS), atau penyakit neoplasma myeloid lainnya. Manajemen kasus ini mengacu pada algoritma tatalaksana berdasarkan 3 faktor risiko mayor untuk thrombosis (riwayat thrombosis, JAK2/MPL mutations, dan usia lanjut). Kasus ini dikatagorikan sebagai pasien risiko tinggi untuk thrombosis, sehingga diberikan anti agregasi platelet (aspilet), dan anagrelide setelah hydroxiurea dinilai tidak responsif.

Kata Kunci Essential thrombocythemia, thrombosis, perdarahan

\section{INTRODUCTION}

Essential thrombocythemia is a clonal disorder with unknown etiology, involving multipotent hematopoiesis progenitor cells with clinical manifestations of excessive thrombocyte production with an unclear cause.. ${ }^{(1,2)}$ The incidence of ET is very rare $1-2 / 100.000$ populations. $^{(1)}$ but the prevalence of ET is estimated at 30 per 100.000 people throughout the world. ${ }^{(3)}$ All ages can be affected by ET but mostly at age $>60$ years with female: male $2: 1 .^{(1,3,4)}$ In the Europe Union region it is estimated that the ET incidence rate is between $0.38 / 100.000$ to $1.7 / 100.000$ population. ${ }^{(5)}$ Populationbased surveys in Sweden, reported an incidence rate of ET 1.55/100,000. ${ }^{(6)}$ The prevalence of ET in United States is estimated around 38-57/100.000 in the period of 2008 $-2013 .{ }^{(7)}$ In Indonesia there is no data of the incidence and prevalence of ET. ${ }^{(8)}$

Symptoms and signs of ET are not specific, 
but ET patients have a hemorrhagic tendency in the form of bleeding in the gums, epistaxis and occurrence of vascular occlusion which may cause erythromelalgia, headache, paresthesia. ${ }^{(1,3,6,8)}$ Diagnosis of ET is more commonly found deliberately from a complete blood test in the diagnosis of an asymptomatic ET patient. ${ }^{(6)}$ The author is interested in raising the case because ET is a rare case and in order to learn more the newest guidelines to treat ET patient

\section{METHODS}

A 74 year old female patient was admitted to the emergency unit of Sanjiwani Hospital, on $8^{\text {th }}$ August 2017 with active gum bleeding. The bleeding was oozing since a few days prior to admission. The total bleeding was approximately $750 \mathrm{ml}$. She also complained headache but she has no sign of dizziness or pre-shock symptoms. There was no history of fall or another trauma. She also has no history of easy bruising or other bleeding tendency. She also reports no fever. There was no known family history of a bleeding disorder. On physical examination she was fully alert, in no apparent of restless or distress. There was hypertension but the other vital signs were under normal limit. There was neither hepatomegaly nor splenomegaly. Another physical examination was within normal limit and there was no neurologic deficit.

On the laboratory tests, the number of WBC, HGB and Thrombocyte were 31.3/ $\mu \mathrm{L}, 5.4 \mathrm{~g} / \mathrm{dL}$ and $2094 / \mu \mathrm{L}$ respectively. On the blood film obtained erythrocytes hypochromic microcytic, poikilocytosis (pencil cells, fragmentocyte, tear drop, target cell, burr cell), without polychromasia and normoblast. Thrombocytes: impression of greatly increased quantities, with giant thrombocytes and thrombocyte groups. Impression supports a myeloproliferative disease (essential thrombocythaemia/ET) with iron deficiency anemia. Bone marrow aspiration and biopsy showed that megakaryocyte cells increased in number and cellssize, broader cytoplasm with multilobulated nuclei. The diagnosis of ET fulfilled the WHO 2016 criteria. The patient was given adrenalin tampon to treat the gum bleeding and also had blood transfusion for hemoglobin correction; then the gum bleeding gradually stopped. She also had Captopril $25 \mathrm{mg}$ bid, for hypertension treatment. Management of ET in this case are low dose aspirin $(80 \mathrm{mg})$ and anagrelide $0.5 \mathrm{mg}$ per day orally, base on the consideration of thrombosis risk. This treatment applied after hydroxyurea unresponsive to therapiutic target.

\section{DISCUSSION}

Essential thrombocythemia is a clonal disorder with an unknown etiology, involving multipotent hematopoiesis progenitor cells with manifestations of excessive thrombocytes production with no apparent cause. ${ }^{(1,2)}$ The incidence rate is a very rare with $1-2 / 100.000$ people. ${ }^{(1)}$ The prevalence of ET is estimated at about 30/100,000 people worldwide. ${ }^{(3)} \mathrm{A}$ survey conducted in Sweden reported an ET incidence of $2.3 / 100,000$ in habitants. There is still no concrete data on epidemiological studies. ${ }^{(8)}$ Essential thrombocythemia affected in all of age, but mostly at $>60$ years with a median age of diagnosed ET are 65-70 years. Women are more often affected than men with a ratio of $2: 1^{(1,3,4)}$. This case is a 74 year-old female patient that came to Sanjiwani Hospital with a gum bleeding. Physical examination reveals an active bleeding on the gum. This symptom is in accordance with the literature that clinical manifestations of ET are $20-50 \%$ of cases showing symptoms of abnormal bleeding, bleeding that occurs mainly on the skin and/or mucosa that may be rash, subcutaneous hematoma, ecchymosis, epistaxis and gum bleeding. The patient also felt headache, but no sign of neurological deficit. This sign is probably due to microvascular thrombosis, but there are no sign of major thrombosis involving cerebrovascular, coronary, and peripheral arterial circulation. Thrombosis in large arteries is a major cause of mortality or can induce neurologi- 
cal, cardiac, and peripheral arterial disorders. ${ }^{(1,3,8-10)}$ Splenomegaly or hepatomegaly can be found in some cases that is about 15 $-20 \%$, but we didn't find in this case.

Essential Thrombocythemia risk classification based on the incidence of complications in the form of high risk to people of age $>60$ years, has a history of thrombosis, thrombocytes $>1500 / \mu \mathrm{L}$. The intermediate risk is $<60$ years of age, thrombocytes $<1500 / \mu \mathrm{L}$, with only mild microvascular disorders, but have risk factors for cardiovascular disease. Low risk at $<60$ years of age, thrombocytes count $<1500 \mu \mathrm{L}$, asymptomatic $^{(6,8)}$. In this case, it happened to a 74 -year-old patient with gum bleeding and thrombocytes level $2094 / \mu \mathrm{L}$ which is a high risk. There is correspondence between case and theory.

In diagnosing of $\mathrm{ET}$, the most recent criteria are modified by WHO in 2016, revision to the World Health Organization classification of myeloid neoplasms and acute leukemia, are the following: ${ }^{(11)}$

Table 1. Diagnostic Criteria of Essential Thrombocythemia (ET) by WHO 2016

\begin{abstract}
WHO (2016): there are the following four major and minor criteria

\section{Major criteria}

1. Platelet count $\geq 450 \times 10^{9} / \mathrm{L}$

2. BM biopsy showing proliferation mainly of the megakaryocyte lineage with increased numbers of enlarged, mature megakaryocytes with hyperlobulated nuclei. No significant increase or left shift in neutrophil granulopoiesis or erythropoiesis and very rarely minor (grade 1) increase in reticulin fibers

3. Not meeting $\mathrm{WHO}$ criteria for BCR-ABL1 ${ }^{+} \mathrm{CML}, \mathrm{PV}, \mathrm{PMF}$, myelodysplastic syndromes, or other myeloid neoplasms

4. Presence of JAK2, CALR, or MPL mutation

\section{Minor criteria}

Presence of a clonal marker or absence of evidence for reactive thrombocytosis

Diagnosis of ET requires meeting all 4 major criteria or the first 3 major criteria and the minor criteria
\end{abstract}

$C M L=$ Chronic myeloid leukemia, $P V=$ Polycythemia Vera, $P M F=$ primary myelofibrosis

On Complete Blood Count was found hemoglobin $5.4 \mathrm{~g} / \mathrm{dL}$, thrombocyte 2.094/ $\mu \mathrm{L}$. On the blood film obtained erythrocytes hypochromic microcytic, poikilocytosis (pencil cells, fragmentocyte, tear drop, target cell, burr cell), without polychromasia and normoblast. Thrombocytes: impression of greatly increased quantities, with giant thrombocytes and thrombocyte groups. Impression supports a myeloproliferative disease (essential thrombocythae$\mathrm{mia} / \mathrm{ET}$ ) with iron deficiency anemia. Bone marrow aspiration and biopsy at Sanglah hospital results in the form of Microscopic:
I-II Aspiration: hypercellular preparations consist of groups of hematopoietic cells containing the series erythroid, myeloid, and megakaryocyte. The myeloid series showed a variety degree of maturation from blast to segment. Megakaryocyte cells showed an increase in the number and morphology of large-sized cells, broad cytoplasm, and multilobulated nuclei. The erythroid cells appear to show a decrease in the number. III. Trephine: the preparation consists of bone trabecular. There are no visible hematopoietic cells in this preparation. Conclusions: Morphological features are appropriate for essential thrombocythemia. Based on the clinical finding, blood film and BMP result, diagnosis of this case 
was met with the WHO 2016 revised criteria for ET.

Essential thrombocythemia (ET) management aims to control thrombocyte count for complications prevention, based on the consideration of the risk level for the occurrence of thrombosis complications. Risk factors for thrombosis are age, thrombosis risk, cardiovascular risk (diabetes, hypertension, smoking, dyslipidemia), and the presence of mutations JAK2 V617F. ${ }^{(1-}$ $3,6,8,12)$

Therapy can be given that is using pharmacological therapy that aims to reduce the number of thrombocytes and thrombocyte function.

1. Anti-thrombocyte drug (to decrease platelet function)

A large randomized study showed a decreased incidence of thrombosis in ET patients receiving aspirin ${ }^{(11)}$. Recent evidence recommends aspirin in all ET patients except those who are contraindicated. The recommended dose is low dose aspirin, which is $40-100 \mathrm{mg} /$ day. Regarding new antiplatelet such as clopidogrel and prasugrel can be used as an alternative to aspirin, but it remains unclear. ${ }^{(11)}$

2. Drug cytoreduction (lowering platelet count)

\section{a. Hydroxycarbamide (Hydroxiurea/} $\mathrm{HC})$

Hydroxycarbamide (Hydroxiurea/ $\mathrm{HC}$ ) is an antimetabolite that primarily acts on cells in S phase. This drug acts by inhibiting activity of enzyme ribonucleoside diphosphate reductase. This enzyme reduces HC ribonucleotide catalysis is the first choice therapy in high risk thrombocythemia patients. This is due to the effectiveness and rarely side effect. The dose of $\mathrm{HC}$ is $15 \mathrm{mg} / \mathrm{kg} \mathrm{BW}$. b. Anagrelide

Anagrelide is an oral compound imidazole (2,1-b) quinazolin-2-one with an inhibitory effect of platelet aggregation by inhibition of cyclic nucleotide phosphodiesterase and phospholipase A2. Anagrelide has been shown to be an alternative therapy in ET. The dose begins with 2 $\mathrm{mg}$ /day (divided into 2-4 doses) and can be increased $0.5 \mathrm{mg}$ /day every 7 days until a targeted platelet count is reached with a maximum dose of 10 $\mathrm{mg} /$ day. Normalization of platelet counts is necessary to minimize the effects of thrombohemorrhage during therapy. Anagrelide is not leukomogenic. Anagrelide is licensed in Europe as second-line therapy in high-risk refractory ET patients or intolerant with first-line therapy.

c. Interferon Alpha (IFN $\alpha)$

IFNa directly inhibits thrombopoie in (TPO), which induces megakaryocytes growth by suppressing TPO that induces signals that stimulate SOCS. Recent studies showed that IFN $\alpha$ in ET patients decreases platelet counts to $<600,000 / \mathrm{mm} 3$ in 3 months at a dose of about 3 million IU/day. Despite the side effects and expensive prices, IFN $\alpha$ is a therapeutic option especially in younger ET patients.

\section{d. Busulphan}

Busulphan is an alkylating drug, in some cases successfully controlling the number of thrombocytes. Manifestations of vascular occlusion may overcome, but the symptoms of bleeding are not. Various doses of Busulphan can be administered, e.g., $60 \mu \mathrm{g} / \mathrm{kg} \mathrm{BW} /$ day/oral (max. $4 \mathrm{mg}$ ) continuously until thrombocyte count decreases $<400,000 / \mathrm{mm} 3$. The dose is stopped until the thrombocyte count rises above normal, a 
continuous dose of cytopenia. The alternative is intermittent doses, e.g., 20-25 mg at 4-6 week intervals.

e. Pipobroman

Pipobroman is a bromide derivative piperazine, which acts as a competitor of pyrimidine base metabolism and is an alkylating drug. It has been used in ET treatment for over 30 years. In the study of French patients treated with Hydroxyurea the rate of transformation for AML was $7.3 \%$, $10.7 \%$ and $16.6 \%$ after 10,15 and 20 years and for patients treated with pipobroman the rate of transformation for AML was $14.6 \%, 34 \%$ and $49.4 \%$ respectively. These data suggest that pipobroman should be used with caution.

In the treatment of cytoreduction drug use, the drug selection is based on age category of ET patients, as the following table: ${ }^{(6,2)}$

Tabel 2. Cytoreduction drug selection is based on age category

\begin{tabular}{ccc}
\hline Age groups (years) & first line & Second line \\
\hline$<40$ years & Interferon & Hydroxyurea, Anagrelide \\
$40-75$ years & Hydroxyurea & Interferon, anagrelide \\
$>75$ years & Hydroxyurea & Anagrelide, pipobroman, busulphan \\
\hline
\end{tabular}

In case of high risk, patients with age of 74 years were given aspirin $80 \mathrm{mg}$ therapy, hydroxyurea $1000 \mathrm{mg}$, and $0.5 \mathrm{mg}$ anagrelide. This is consistent with the theory of high-risk ET patients with age between 40-75 years to be given antithrombocyte drugs (aspirin), and second line anagrelide after the first-line hydroxyurea cytoreduction clinically unresponsive. The target treatment is to maintain the level of thrombocyte count $<600 \times 10^{9} /$ L. $^{(10)}$

\section{SUMMARY}

We reported a 74 year-old female patient who has met the criteria diagnosis of ET according to WHO 2016. The patient was given therapy in accordance with ET management theory with aspirin $80 \mathrm{mg}$ and anagrelide $0.5 \mathrm{mg}$ per day orally after hydroxyurea unresponsive to therapeutic target. This is for prevention of thrombosis risk and lowering thrombocyte count to achieve targeted therapy.

\section{CONFLICT OF INTEREST}

The authors declare no conflict of interest regarding the publication of this paper.

\section{ACKNOWLEDGMENT}

This case is supported by Ery Purnama Warsana, IK, student of Warmadewa University of Faculty of Medical and dr. Renny A Rena, Sp.PD-KHOM, Staff of Hematology -Medical Oncology, Departement of Internal Medicine, Faculty of Medicine, University of Udayana, Sanglah Hospital, Bali, Indonesia

\section{REFERENCES}

1. LJ Spiyak. Harrison's Principal of Internal Medicine. 19th Ed. Mc Graw Hill Educ. 2015;676-8.

2. I Alwi, S. Salim, R Hidayat, J Kurniawan DLT. Penatalaksanaan di Bidang Ilmu Penyakit Dalam Panduan Praktik Klinis. 2015. 551-4 p.

3. M A Papadakis SJM. Current Medical Diagnosis and Treatment. In: Mc Graw Hill 1Medical. 2013. p. 513-5.

4. Institutet K. Clinical and Epidemiological Studies in Malin Hultcrantz Stockholm 2013. 2013.

5. Moulard O, Mehta J, Fryzek J, Oli- 
vares R, Iqbal U, Mesa RA. Epidemiology of myelofibrosis, essential thrombocythemia, and polycythemia vera in the European Union. Eur J Haematol. 2014;92(4):289-97.

6. Briére JB. Essential thrombocythemia. Orphanet J Rare Dis. 2007;2 (1):1-17.

7. Mehta J, Wang H, Iqbal SU, Mesa R. Epidemiology of myeloproliferative neoplasms in the United States. Leuk Lymphoma. 2014;55(3):595600 .

8. Oehadian A. Aspek Hematologi Tuberkulosis. 2003;

9. Bakta IM. Hematologi Klinik Ringkas. In: Buku Kedokteran EGC.
2011. p. 1472-82.

10. Hernández-Boluda JC, Gómez M. Target hematologic values in the management of essential thrombocythemia and polycythemia vera. Eur J Haematol. 2015;94(1):4-11.

11. Arber DA, Orazi A, Hasserjian R, Borowitz MJ, Beau MM Le, Bloomfield $\mathrm{CD}$, et al. The 2016 revision to the World Health Organization classification of myeloid neoplasms and acute leukemia. Blood. 2016;127 (20):2391-406.

12. Rumi E, Cazzola M. How I treat How I treat essential thrombocythemia. Blood. 2016;128(20):2403-14. 